\title{
Detection of heroin metabolites at different developmental stages of Lucilia cuprina (Diptera: Calliphoridae) reared in heroin- treated meat: a preliminary analysis
}

\author{
Nooratiny Ishak', Abu Hassan Ahmad², Siti Azizah Mohamad Noor ${ }^{2}$ and Azwandi Ahmad ${ }^{3 *}$ (i)
}

\begin{abstract}
Background: Blowfly larvae and pupae collected during post-mortem forensic investigation can be analysed to detect drugs or toxins in a dead body. Drug or toxin-contaminated tissues of human remains consumed by blowfly larvae are stored in the crop even after a body has decomposed to the point where no fluid or tissues are retrievable. Therefore, blowfly larva and pupa are favourable specimens under conditions in which host tissues or blood samples are not available.

Methodology: We carried out a study to detect heroin metabolites in Lucilia cuprina (Weidemann, 1830) immatures fed on different concentrations of heroin-treated meat: 500, 1000, 2500, 5000, and 10,000 ng/ $\mu$. Heroin metabolites detection was performed by a gas chromatography mass spectrophotometry (GCMS) analysis.

Results: This study indicates that L. cuprina can be utilized in a toxicological analysis to detect heroin in a host. However, the expected complete metabolites of heroin were not detected in the first instar larvae and pupa, while the second and third instar larvae contributed to a complete heroin metabolite which was morphine. This was subject to the heroin concentration given. Morphine was detected in the third instar larvae treated with 5000 and 10,000 ng/ $\mathrm{\mu l}$ heroin, while in the second instar, it was detected only at 10,000 $\mathrm{ng} / \mu \mathrm{l}$. Heroin metabolites detected in the second and third instar larvae proves that biochemical conversions occur in the fly larvae.

Conclusion: The absence of heroin metabolites in the first instar larvae and pupa does not necessarily mean that the drug was not present in the host. Therefore, the limitations of heroin detection capability during these stages should be always kept in mind, as this could contribute to a false-negative result in a forensic analysis. If all stages are available during sample collection, it is crucial to prioritize the third instar larvae in a toxicological analysis.
\end{abstract}

Keywords: Entomotoxicology, Lucilia cuprina, Heroin, Morphine, Post-mortem

\section{Background}

In the decomposition of human remains, every stage of decay is associated with specific insects, starting from flies to beetles, and finally moths. However, the most important insects in this process are flies from the family Calliphoridae, especially those from the subfamily Chrysomyinae, Calliphorinae, and Lucillinae. They are among

\footnotetext{
* Correspondence: azwandi2012@gmail.com

${ }^{3}$ Department of Pharmaceutical Life Science, Faculty of Pharmacy, Universiti Teknologi MARA Selangor, Puncak Alam Campus, 42300 Bandar Puncak Alam, Selangor, Malaysia

Full list of author information is available at the end of the article
}

the first insects to arrive on human remains for oviposition. After hatching, their offspring consume dead tissue (Wells et al. 2001a, 2001b). Fly offspring or larvae serve as a repository for drugs once they have consumed drug-contaminated tissues. As a result, they can be utilized in a toxicological analysis for drug detection, especially under conditions in which host tissue samples are not available or viable. Drug-contaminated tissues consumed by larvae are stored in the crop until they reach the pupal stage, so they serve as "living preservation capsules" of tissues from the deceased. However, when the pupal stage begins, digestion and metamorphosis occur, 
leading to a significant drop of drug concentration, meaning that the pupal stage has less forensic importance (Sadler et al. 1995).

It is well-documented that drugs accumulated in fly larvae could alter their normal life cycle duration (Goff et al. 1989; Bourel et al. 2001) as well as changing body weight and length (Oliveira et al. 2009). For example, morphine and heroin may accelerate larval development growth rate and slow development rate in the pupal stage (Carvalho et al. 2001). A study on Lucilia sericata (Meigen 1826) (Diptera: Calliphoridae) showed similar findings which heroin speed up their growth rate (Bourel et al. 2001). The pupal casing of $L$. sericata has been found to shed earlier at a higher concentration of morphine compared to a lower concentration (Bourel et al. 2001). Moreover, L. sericata larvae reared in rabbits treated with tramadol was noted reached maximum sizes earlier than in larvae reared on the control rabbit (ElSamad et al. 2011). Along with changes in developmental rates and variation in the size of larvae during their development, the presence of drugs or toxic substances in the insect food source can also be validated (Wells et al. 2001a, 2001b). Various drugs have been detected in different stages of fly development, such as amitriptyline (Sadler et al. 1997a; Wilson et al. 1993), phenobarbital (Beyer et al. 1980), lorazepam (Wood et al. 2003), amphetamine (Sadler et al. 1997b), cocaine (Nolte et al. 1992; Campobasso et al. 2004), codeine (Kharbouche et al. 2008), morphine (Hedouin et al. 1999), and methadone (Gosselin et al. 2010).

For drug detection, larval specimens in a forensic case are only useful if they are collected alive and properly preserved to ensure that minimal putrefactive fluids are produced from their own decomposition process. Forensic toxicological analysis of dead tissues from larvae would be misleading if these criteria were not met due to contamination of the sample with larvae putrefaction fluids (Levine et al. 2000; Kintz et al. 1990a, 1990b). Considering the impact of drugs on a normal fly life cycle and developmental rate, the identification of drug metabolites in each fly developmental stage is critical. Moreover, the pharmacokinetics of drugs in an insect is known to be influenced by the developmental stage, as well as species and feeding activity (Kharbouche et al. 2008). Therefore, we conducted a preliminary analysis with the objective of identifying both complete and noncomplete heroin metabolites in each developmental stage of L. cuprina reared on heroin-treated meat prepared with five different concentrations. An unusual approach was used in this study in which heroin-treated meat was used, instead of an animal model. This considers a possibility that larvae could also have a chance to consume unmetabolized heroin in a forensic case. This study emphasizes detecting heroin metabolites in larvae consuming an unmetabolized drug; therefore, drug metabolism factors are excluded if a living animal model was used.

\section{Methods \\ Maintaining stock culture for Lucilia cuprina}

A sweep net was used to capture adult $L$. cuprina hovering or landing on bait prepared from fresh minced buffalo meat obtained from a local wet market. The captured flies were immediately transferred into an insect cage $(30 \mathrm{~cm} \times 30 \mathrm{~cm} \times 30 \mathrm{~cm})$ and brought back to the insectarium at the School of Biological Sciences, Universiti Sains Malaysia, for culturing at $29 \pm 3{ }^{\circ} \mathrm{C}$, under a photoperiod of $13 \mathrm{D}: 11 \mathrm{~L}$ and $\mathrm{RH}$ of $75 \pm 10 \%$. The flies were fed two kinds of food: a mixture of $10 \%$ (w/v) sugar solution for adult and minced buffalo meat for fly oviposition. For the oviposition substrate, $500 \mathrm{~g}$ minced buffalo meat was placed in three petri dishes. The eggs observed from each petri dish were then transferred gently into a larva-rearing box containing $50 \mathrm{~g}$ minced buffalo meat. The larval development was monitored until pupation. When pupae were observed, they were transferred using forceps into a new container containing sterile fine sand; each container was then placed into an individual insect cage. Once the adult flies emerged, a mixture of $10 \%(\mathrm{w} / \mathrm{v})$ sugar solution was provided as adult food. The first-generation adults were identified using a blowfly taxonomic identification key (Wallman 2001). Flies confirmed to be L. cuprina were reared until the third generation following the process described above. The eggs of that generation were then collected and used for subsequent experiments.

\section{Application of heroin onto minced buffalo meat}

Lyophilized heroin was prepared in saline to obtain concentrations of 500, 1000, 2500, 5000, and 10,000 ng/ $\mu \mathrm{l}$. Each heroin preparation was mixed with minced buffalo meat purchased from a wet market in a volume to weight ratio of 1:100 (I.E., $5 \mathrm{ml}: 500 \mathrm{~g}$ ) using a food processor to ensure a homogenous mixture. Minced buffalo meat that was not mixed with heroin (untreated) served as the control treatment. Each preparation of herointreated minced buffalo meat and untreated meat was then placed into half-filled sterile sand plastic containers and covered with a fabric mesh. A clump of L. cuprina eggs was placed onto each buffalo meat preparation, and the treatments were replicated five times. Every 8 h, 10 individual first instar larvae, 10 individual second instar larvae, and 10 migrating third instar larvae were harvested and cleaned, and their body length was measured. Larva instar stages were determined based on the characteristics of posterior spiracles. The larvae were then preserved for toxicological and molecular analysis following the method described below. 


\section{Dissecting the crop of Lucilia cuprina for toxicological analysis}

Ten collected larvae from each harvesting were rinsed with distilled water to remove any foreign particles or other possible contamination that adhered to the larvae during previous procedures. The collected larvae were then labelled, preserved alive, and stored at $-20{ }^{\circ} \mathrm{C}$ for toxicology analysis. For the first and the second instar larvae, the whole larvae tissue was used in the toxicology analysis because the crop was too small to be dissected by using a dissecting microscope (Carls Zeiss, United State). However, the third instar larvae were dissected to bring out the crop using a dissecting microscope. Before carrying out the dissection procedure, all larvae were washed with sterilized water to remove any possible contamination present on the external of the larval body. The cleaned larvae were placed under the dissecting microscope on a new sterile petri dish, and the instar of each larva was recorded based on the posterior spiracle's characteristics. Only the third instar larvae of $10 \mathrm{~mm}$ in length were dissected for toxicology analysis purposes. After that, the posterior segment was cut using a sterilized scalpel, followed by a ventral incision to the anterior of the larvae. Later, each crop was removed using sterilized forceps and placed in a $1.5 \mathrm{~mL}$ Eppendorf tube for toxicological analysis. The working area was wiped with $70 \%$ alcohol before and after the procedure. The dissection was performed based on the standard method (Linville and Wells 2002).

\section{Toxicological analysis}

In the toxicological analysis, an alkali-acid base extraction was used, followed by gas chromatography mass spectrophotometry (GCMS) analysis (Agilent 6890 GC). The toxicological analysis adopted in this study adhered to an accredited test recommended by Jabatan Kimia Forensik Malaysia (The Forensic Chemistry Department of Malaysia) with identification number 0537 (JKMF0537). The GCMS was conducted with an Agilent GC instrument using a 5973-mass selective detector (MSD) and a non-polar column HP-5. Helium gas was applied as the carrier gas at a constant current rate of $2 \mathrm{ml} /$ minutes, where $1 \mathrm{ul}$ of the extract was injected in a split mode (40:1). The temperatures for the injector and the detector (transfer line) were set at $250{ }^{\circ} \mathrm{C}$ and $280{ }^{\circ} \mathrm{C}$, respectively. The analysis was conducted at a temperature of $80{ }^{\circ} \mathrm{C}$ for $2 \mathrm{~min}$; then increased to 150 ${ }^{\circ} \mathrm{C}$ at $20{ }^{\circ} \mathrm{C} /$ minute and held for $2 \mathrm{~min}$; to $280{ }^{\circ} \mathrm{C}$ at $10{ }^{\circ} \mathrm{C} /$ minute and held for $5 \mathrm{~min}$; and to $20{ }^{\circ} \mathrm{C} / \mathrm{min}$ to $30{ }^{\circ} \mathrm{C}$ and held for $14 \mathrm{~min}$. All the results obtained were analysed using the toxicology library available in the instrument.

\section{Results}

Overall ion chromatogram of tryptophan and morphine obtained from the third instar larvae are presented in
Figs. 1 and 2, respectively. Meanwhile, information concerning mass spectral characteristics of tryptophan and morphine obtained from the third instar larvae are illustrated in Figs. 3 and 4, respectively. However, the mass spectral characteristics and the ion chromatogram could not be obtained for hydromorphone, because the metabolic yield was less than $50 \%$ than that of tryptophan and morphine.

Table 1 shows the mass to charge ratio and the quality of heroin metabolites measured in immature stages of $L$. cuprina reared on minced buffalo meat treated with different concentrations of heroin. At each sampling time, all analysed second and third instar larvae tested positive for heroin metabolites. In contrast, heroin metabolites were not detected in the first instar larvae and pupae. Tryptophan was detected in the second instar larvae reared on the 500, 1000, and $2500 \mathrm{ng} / \mu \mathrm{l}$ of herointreated meat, while morphine was detected in the second instar larvae reared on 10,000 and $5000 \mathrm{ng} / \mu \mathrm{l}$ of herointreated meat. Meanwhile, the metabolites detected in third instar larvae consisted of the following: hydromorphone for larvae reared on 500 and $1000 \mathrm{ng} / \mu \mathrm{l}$ of heroin-treated minced meat; tryptophan for larvae reared on $2500 \mathrm{ng} / \mu \mathrm{l}$ of heroin-treated meat; and morphine for larvae reared on the 5000 and $10,000 \mathrm{ng} / \mu \mathrm{l}$ of heroin-treated meat (Table 1).

The quality of tryptophan detected in the second instar larvae increased from $16 \%$ to $27 \%$ when heroin concentration increased from $500 \mathrm{ng} / \mu \mathrm{l}$ to $2500 \mathrm{ng} / \mu \mathrm{l}$. On the other hand, the quality of morphine was detected to increase drastically from $11 \%$ to $95 \%$ in the second instar larvae that were collected from the $5000 \mathrm{ng} / \mu \mathrm{l}$ of heroin-treated meat compared to the $10,000 \mathrm{ng} / \mu \mathrm{l}$ of heroin-treated meat, respectively. However, the quality of hydromorphone in the third instar larvae reared on the $500 \mathrm{ng} / \mu \mathrm{l}$ of heroin-treated meat, and the $1000 \mathrm{ng} / \mu \mathrm{l}$ of heroin-treated meat was low at $1 \%$ and $9 \%$, respectively.

Nonetheless, the highest quality of morphine at $96 \%$ was detected in the third instar larvae reared on the $5000 \mathrm{ng} / \mu \mathrm{l}$ of heroin-treated meat, whereas the highest quality of tryptophan at $53 \%$ was detected in the third instar larvae reared on the $2500 \mathrm{ng} / \mu \mathrm{l}$ of heroin-treated meat (Table 1). Moreover, the third instar larvae collected from 5000 and 10,000 $\mathrm{ng} / \mu \mathrm{l}$ of heroin-treated meat produced positive results for morphine.

The toxicological analysis adopted for this study allowed for the rapid identification of heroin analytes, including tryptophan, hydromorphone, and morphine. The mass to charge ratio for tryptophan in the second instar larvae reared on the 500, 1000, and $2500 \mathrm{ng} / \mu \mathrm{l}$ of heroin-treated meat were $3.75,4.78$, and $3.76 \mathrm{~m} / \mathrm{z}$, respectively, while at the concentrations of 5000 and 10, $000 \mathrm{ng} / \mu \mathrm{l}$, the second instar larvae were found to have 
Abundance

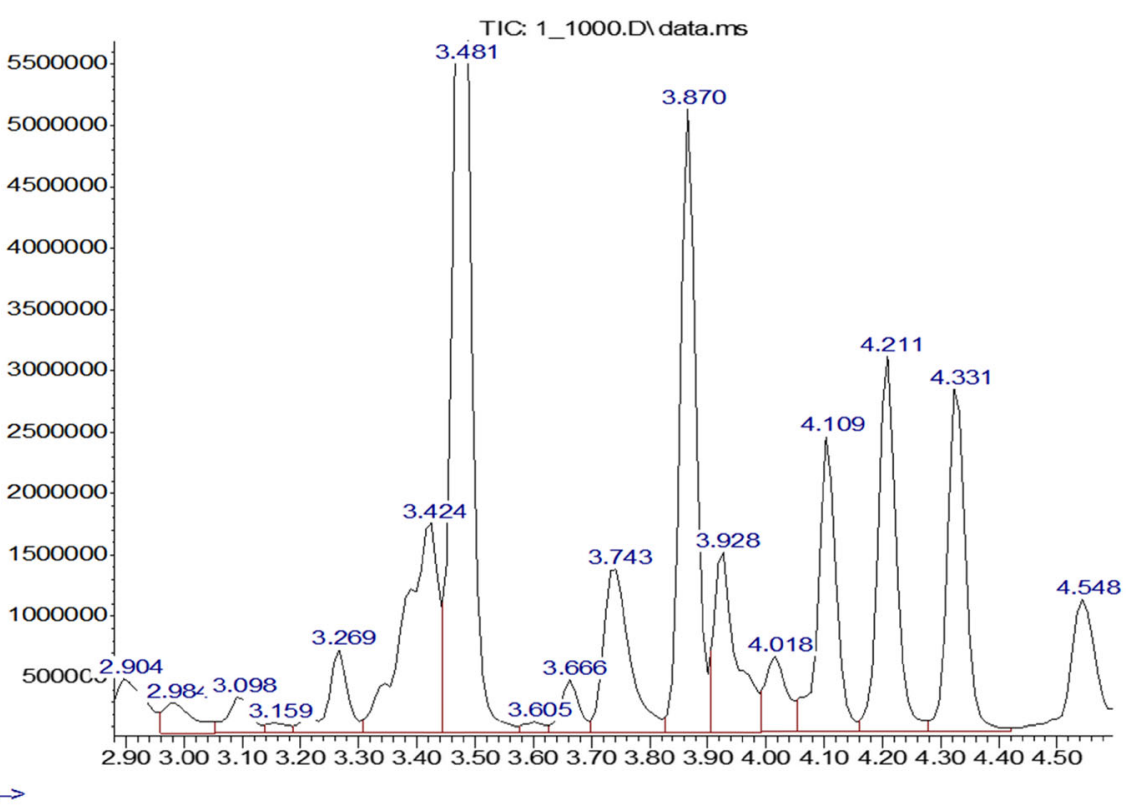

Fig. 1 Total ion chromatogram of Tryptophan 2,4-dimethoxy-5-ethoxyamphetamine (3.74 m/z) in the third instar larvae of L. cuprina after hydrolysis

completely metabolized the heroin to morphine at a mass to charge ratio of $3.60 \mathrm{~m} / \mathrm{z}$.

The mass to charge ratio of hydromorphone in the third instar larvae reared on the 500 and the $1000 \mathrm{ng} / \mu \mathrm{l}$ of heroin-treated minced buffalo meat had 8.06 and $3.32 \mathrm{~m} / \mathrm{z}$, respectively. Other than that, the mass to charge ratio for tryptophan in the third instar larvae reared on the $2500 \mathrm{ng} / \mu \mathrm{l}$ of heroin-treated minced buffalo meat was $3.74 \mathrm{~m} / \mathrm{z}$; whereas in the 5000 and the $10,000 \mathrm{ng} / \mu \mathrm{l}$ of heroin-treated minced buffalo meat, the mass to charge ratio for morphine was $4.94 \mathrm{~m} / \mathrm{z}$ (Table 1$)$.

\section{Abundance}

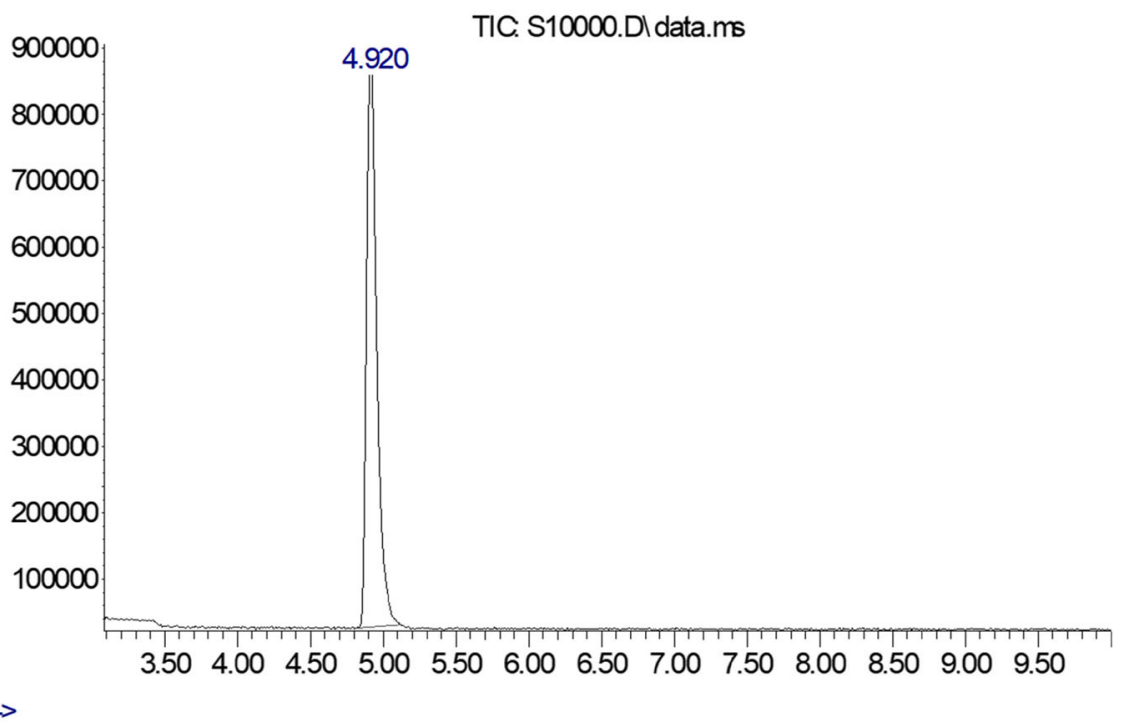

Fig. 2 Total ion chromatogram of Morphine $(4.94 \mathrm{~m} / \mathrm{z})$ in the third instar larvae of L. cuprina after hydrolysis 


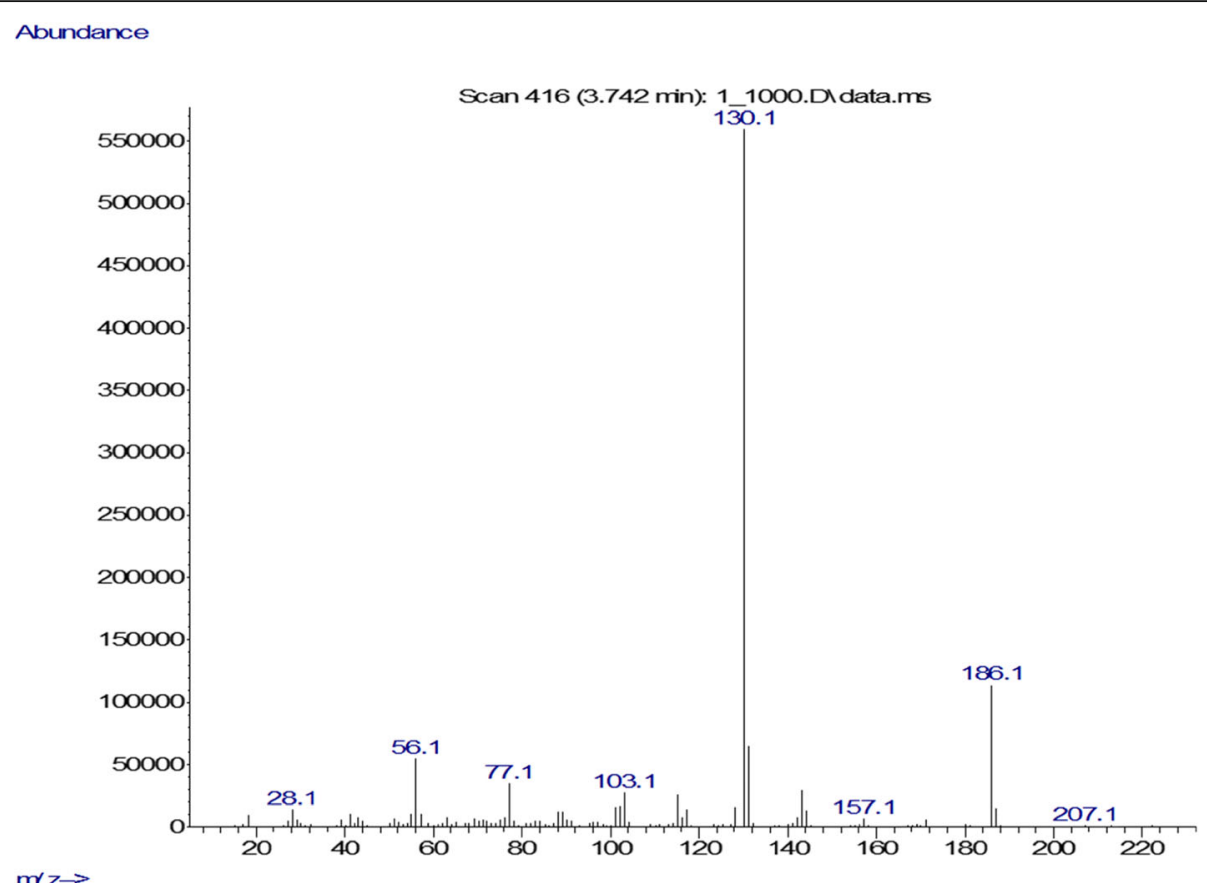

Fig. 3 Mass spectral characteristics of Tryptophan 2,4-dimethoxy-5-ethoxyamphetamine in the third instar larvae of L. cuprina after hydrolysis

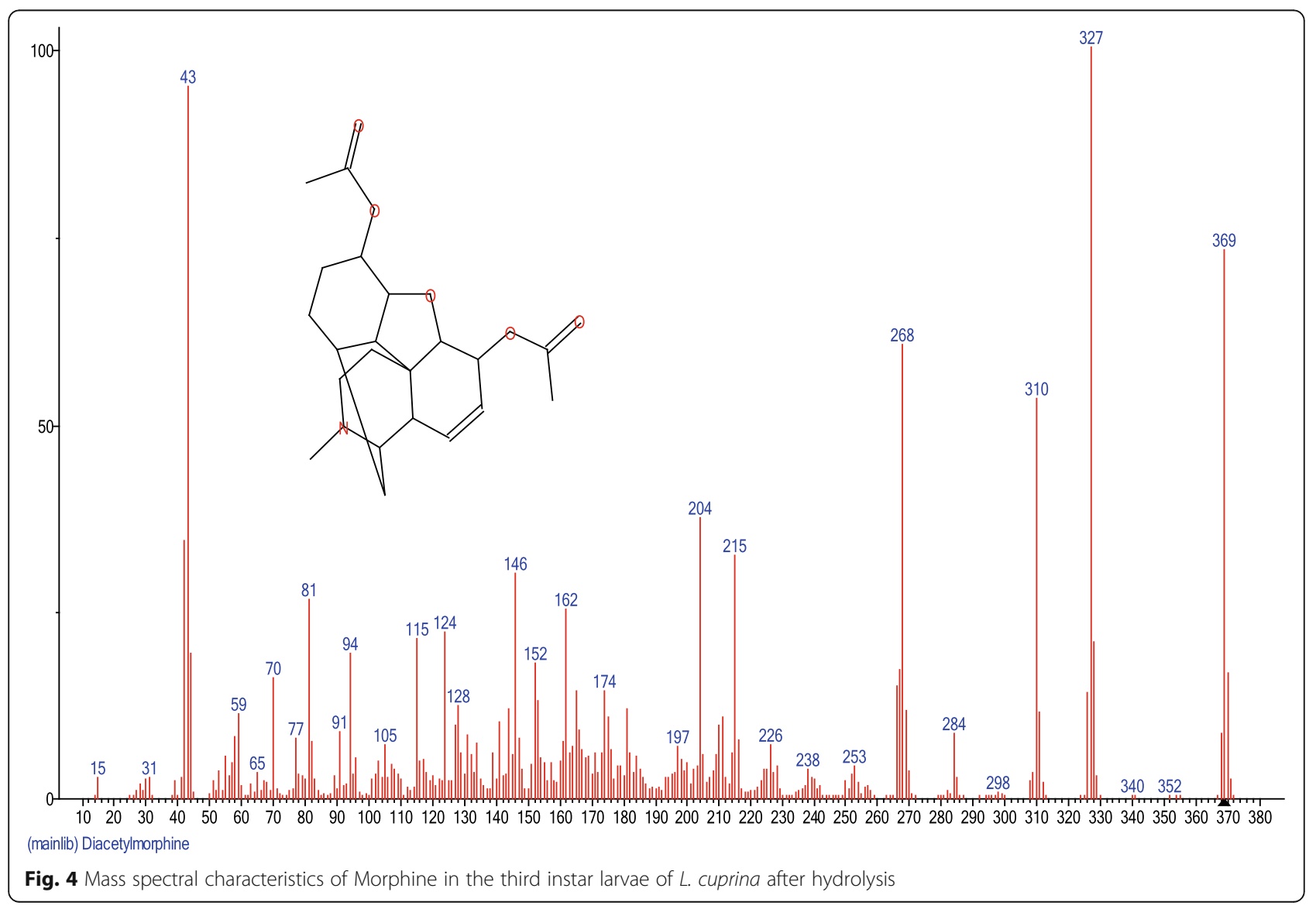




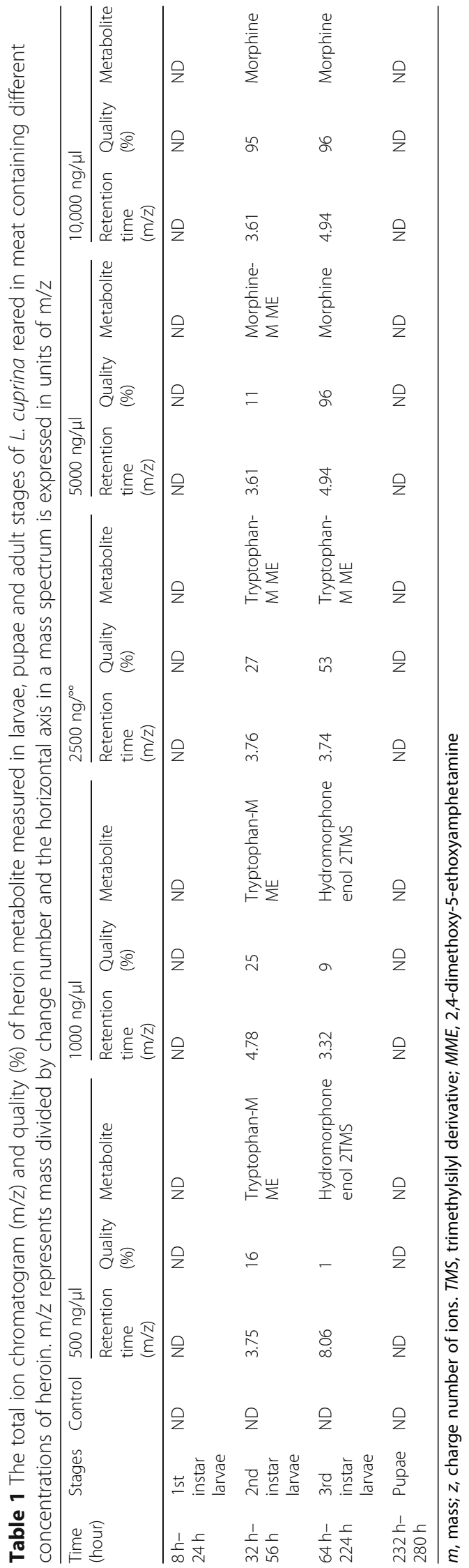




\section{Discussions}

In an entomotoxicology research set-up, drug-treated meat has one advantage compared to heroin-treated animal model, in that the concentration of heroin prior to feeding can be fixed. In an animal model, for instance drug-injected rats or rabbits, the rate of drug concentration to be fed on to larvae is uncontrolled and varies depending on current body metabolism and multiple other unknown internal and external factors. In contrast, however, in drug-prepared meat, the drug concentration before treatment is fixed; therefore, pre- and post-treatment results can be compared quantitatively using an adequate number of replicates. Even though living animals such as rats or rabbits are more suitable models and realistic to represent actual forensic scenario, reports have indicated that correlations between drugs inside human or animal tissue and feeding larvae have not been found due to unknown and complicating factors (Definis-gojanovic et al. 2007; Gosselin et al. 2011). Therefore, the effects of drug concentration on heroin metabolism before and after feeding are impossible to evaluate. In contrast, by using heroin-treated meat, this non-correlation issue is eliminated, and larval pre-feeding concentration can be controlled. Even though in reality, two metabolisms (in human body and fly larvae) are involved in routine forensic analysis and casework, the purpose to understand heroin metabolism in larvae in our case is achievable by using drug-treated meat.

We also consider the possibility that larvae could consume pure or unmetabolized heroin in a forensic case. If drug is taken by snorting powdered form, its residue on or around a dead body or clothing might also be consumed by fly larvae; therefore, first metabolism may begin in the feeding larvae. Although this is uncommon, as no such case has been reported, a record showed fatality rate, resulting from an overdose of heroin that involves routes of administration other than injection, is rather high (i.e. snorting or smoking) (Thiblin et al. 2004). Therefore, there is a chance that larvae could consume drug residue. If larvae had consumed drug residue, in this case, unmetabolized heroin, its metabolites in larvae would be important to be addressed. Moreover, some amount of unmetabolized heroin can remain in urine and therefore could be consumed by larvae.

Through a series of toxicological analysis on heroinfeeded L. cuprina, we have detected the three heroin metabolites of tryptophan, hydromorphone, and morphine. However, the metabolites were identified in the second and third instar larvae, but not in the first instar and pupa. In agreement with this finding, previous work has reported negative results for morphine in the pupae reared on a substrate spiked with high morphine concentration. They concluded that it was due to rapid elimination by the larval stages (Kharbouche et al. 2008).
In contrast, different results were observed when morphine was detected in pupal cases and desiccated adults reared on minced-beef meat (Bourel et al. 2001). In addition to morphine, there are many other drugs detected in the puparium. For instance, cocaine was found in a pupal case of Calliphora vicina Robineau-Desvoidy, 1830 (Nolte et al. 1992), and amitriptyline was detected in pupal cases of Phoridae (Miller et al. 1994). Metabolites of methylenedioxyamphetamine (MDMA) were found in fly puparia, but not in the blood, liver, and larvae collected from tissues treated with 3,4-methylenedioxymethamphetamine, contradicting our study (Goff et al. 1997).

The absence of heroin metabolites at the pupal of $L$. cuprina showed an efficiency of metabolism and elimination of heroin during the larval stage. Similar findings were displayed for $L$. sericata pupae, suggesting that morphine has a rapid elimination rate (Kharbouche et al. 2008). Other factors might be associated with food storage location in the crop and rapid expansion and digestion of food during the post-feeding stage. These processes decrease the drug concentration in larvae, as well as the rate of drug elimination and absorption, resulting in a lack of heroin metabolites in both pupa and adult stages.

In our study, the third instar larvae showed high-quality morphine as compared to the second and the first instar larvae. This high-quality morphine detected from $5000 \mathrm{ng} /$ $\mu \mathrm{l}$ and $10,000 \mathrm{ng} / \mu \mathrm{l}$ heroin concentrations justified the potential use of carrion-feeding insects for drug detection; therefore it can be an alternative toxicological specimen to that of direct testing of tissues from a corpse. The differences among stages might be due to the heterogeneous accumulation and elimination rates of morphine by specific developmental stage of fly, as pharmacokinetics of drugs is known as stage-dependence (Kharbouche et al. 2008). For example, active feeding larvae could have an absorption rate that exceeded the elimination rate. In contrast, elimination rate of non-feeding stage exceeded the absorption rate, therefore inducing a decrease in the opiate concentration in non-active larvae (Campobasso et al. 2004; Pien et al. 2004). Moreover, similar findings were present for opiate metabolism, as it has been observed that morphine has a rapid elimination rate (Kharbouche et al. 2008). The study had also found that codeine was not detected in the prepupa stage, unless they were reared in $30 \mathrm{mg} / \mathrm{kg}$ concentration, which was the highest level in the study. Therefore, undetected morphine during the pupa stage in our study is not unusual and has been explained by previous reports.

The high quality of morphine was detected in the third instar larvae in our study; it could also be related to the accumulation of morphine in adipocytes or integumentary cells. This built-up has been known for facilitating the excretion process by the Malpighian tubules in the 
third instar larvae (Bourel et al. 2001). Therefore, in toxicological analysis, the chance of tracing a high concentration of morphine is better at this stage. The ability of the third instar larvae to accumulate morphine is considered as an advantage and should be emphasized in the future study. Even though it was suggested that the third instar larvae are the most appropriate stage for toxicological analysis (Kharbouche et al. 2008; Sadler et al. 1995), the drug metabolism and pharmacokinetics in third instar larvae are still not adequately understood.

In a toxicological analysis of an advance decay dead body, putrefied tissue is not a recommended specimen for drug detection due to potential disturbance of extraction recoveries, chromatographic performances, as well as low separation and ionization efficiencies. These interruptions are making the drugs not turn up in the analysis (Skopp et al. 2001; Schloegl et al. 2006). With regard to this, fly larvae is a better candidate for drug analysis instead of putrefied tissue. In toxicological analysis, fly larvae have been reported to offer greater sensitivity compared to putrefied tissue or product from human remains (Kintz et al. 1990a, 1990b).

The data obtained in this study is preliminary; therefore it's immature to directly be used as a reference or to apply in actual forensic case works. Nevertheless, it can be a subject for comparison to any similar future research when rats (i.e. liver) are chosen as fly rearingfood. Moreover, comparison of data from both settings is useful as Duke (2004) mentioned that comparisons of spiked foodstuff versus live-animal models should be carried out with a standardized experimental protocol for both experiments.

Despite the limited findings obtained in this study, we have pointed up a potential forensic use of $L$. cuprina. In a case where other biological samples, such as human tissues or blood are in an advanced state of decomposition or unavailable, the immature stages of fly become the best alternative substrate to be used for toxicological analysis. However, if drug metabolism in larvae is not fully understood, forensic examination might be compromised.

\section{Conclusions}

Even though heroin metabolites were detected at only two life stages of L. cuprina, the findings are still indicative of the potential of carrion-feeding insects as alternative toxicology specimens. Third instar larvae are excellent reliable specimens for toxicological analysis, as they can be used to detect the complete heroin metabolite before it is eliminated. However, the mechanism of how larvae metabolize drugs has not been extensively studied, and there is limited literature discussing the discovery of the metabolic products of drugs in fly larvae. Therefore, upcoming research may emphasize this aspect, as well as the pharmacokinetics of the drug in larvae of different species.

\section{Acknowledgements}

This work was conducted by the help of School of Biological Sciences, Universiti Sains Malaysia, Pulau Pinang and Department of Chemistry of Malaysia, Selangor, Malaysia

\section{Adherence to national and international regulations Not applicable.}

\begin{abstract}
Authors' contributions
AA (corresponding author) contributed to conception and design of study, data collection, data analysis and interpretation of data, and drafting and writing the manuscript, and $\mathrm{NI}, \mathrm{AHA}$, SAMN (co-authors) contributed to data analysis, revising the manuscript critically for important intellectual content and approval the version of manuscript for publication.
\end{abstract}

\section{Authors' information}

Dr. Azwandi has a PhD degree in Biomedical Sciences from National University of Malaysia and currently a Senior Lecturer in Faculty of Pharmacy, UiTM Selangor, Malaysia. He has published several articles in both local and international journal related to carrion ecology and forensic entomology. Dr Nooratiny Ishak is a scientific officer at Biotechnology Division, Department of Chemistry Malaysia, 46661 Jalan Sultan, Petaling Jaya, Selangor. She currently working in analysing molecular evidence in forensic cases in Malaysia

Dr. Abu Hassan Ahmad is a Professor in entomology who has supervised significant numbers of postgraduate student at Universiti Sains Malaysia, Penang. He is a leading expert in Medical Entomology.

Dr. Siti Azizah Mohamad Noor is a Professor in molecular ecology and population genetics who has supervised many Masters and PhD student in Universiti Sains Malaysia, Kuala Lumpur. He is an expert in molecular biology.

Funding

No funding.

Availability of data and materials

Data is available.

Ethics approval and consent to participate

No human or animal involved in the study, therefore ethical approval was waived. Consent to participate is not applicable.

Consent for publication

Not applicable.

\section{Competing interests}

The authors declare that they have no competing interests.

\section{Author details}

'Department of Chemistry, Biotechnology Division, Jalan Sultan, 46661 Petaling Jaya, Selangor, Malaysia. ${ }^{2}$ School of Biological Sciences, Universiti Sains Malaysia, 11800 Minden, Pulau Pinang, Malaysia. ${ }^{3}$ Department of Pharmaceutical Life Science, Faculty of Pharmacy, Universiti Teknologi MARA Selangor, Puncak Alam Campus, 42300 Bandar Puncak Alam, Selangor, Malaysia.

Received: 2 November 2018 Accepted: 11 November 2019

Published online: 11 December 2019

\section{References}

Beyer JC, Enos WF, Stajic M (1980) Drug identification through analysis of maggots. J Forensic Sci 25(2):411-412

Bourel B, Fleurisse L, Hedouin V, Cailliez JC, Creusy C, Gosset D, Goff ML (2001) Immunohistochemical contribution to the study of morphine metabolism in Calliphoridae larvae and implications in forensic entomotoxicology. J Forensic Sci 46(3):596-599

Campobasso CP, Gherardi M, Caligara M, Sironi L, Introna F (2004) Drug analysis in blowfly larvae and in human tissues: a comparative study. Int I Legal Med 118(4):210-214

Carvalho LM, Linhares AX, Trigo JR (2001) Determination of drug levels and the effect of diazepam on the growth of necrophagous flies of forensic importance in southeastern Brazil. Forensic Sci Int 120(1-2):140-144 
Definis-Gojanovic M, Sutlovic D, Britvic D, Kokan B (2007) Drug analysis in necrophagous flies and human tissues. Arh Hig Rada Toksikol 58:313-316

Duke LD (2004) In: Cprc (ed) Method validation for amitriptyline and nortriptyline in artificial foodstuff, Ottawa, pp 1-183

El-Samad LM, El-Moaty ZA, Makemer HM (2011) Effects of tramadol on the development of Lucilia sericata (Diptera: Calliphoridae) and detection of the drug concentration in postmortem rabbit tissues and larvae. J Entomol 8(4): 353-364

Goff ML, Miller ML, Paulson JD, Lord WD, Richards E, Omori Al (1997) Effects of 3,4-methylenedioxymethamphetamine in decomposing tissues on the development of Parasarcophaga ruficornis (Diptera:Sarcophagidae) and detection of the drug in postmortem blood, liver tissue, larvae, and puparia. J Forensic Sci 42(2):276-280

Goff ML, Omori Al, Goodbrod JR (1989) Effect of cocaine in tissues on the development rate of Boettcherisca peregrina (Diptera: Sarcophagidae). J Med Entomol 26(2):91-93

Gosselin M, Ramirez Fernandez MDM, Wille SMR, Samyn N, De Boeck G, Bourel B (2010) Quantification of methadone and its metabolite 2-ethylidene-1,5dimethyl-3,3-diphenylpyrrolidine in third instar larvae of Lucilia sericata (Diptera: Calliphoridae) using liquid chromatography-tandem mass spectrometry. J Anal Toxicol 34(7):374-380

Gosselin M, Wille SM, Fernandez MM, Di Fazio V, Samyn N, De Boeck G, Bourel B (2011) Entomotoxicology, experimental set-up and interpretation for forensic toxicologists. Forensic Sc. Int 208:1-9

Hedouin V, Bourel B, Martin-Bouyer L, Becart A, Tournel G, Deveaux M, Gosset D (1999) Determination of drug levels in larvae of Lucilia sericata (Diptera: Calliphoridae) reared on rabbit carcasses containing morphine. J Forensic Sci 44(2):351-353

Kharbouche H, Augsburger M, Cherix D, Sporkert F, Giroud C, Wyss C, Champod C, Mangi P (2008) Codeine accumulation and elimination in larvae, pupae, and imago of the blowfly Lucilia sericata and effects on its development. Int J Legal Med 122(3):205-211

Kintz P, Godelar B, Tracqui A, Mangin P, Lugnier AA, Chaumont AJ (1990a) Fly larvae: a new toxicological method of investigation in forensic medicine. J Forensic Sci 35(1):204-207

Kintz P, Tracqui A, Ludes B, Waller J, Boukhabza A, Mangin P, Lugnier AA Chaumont AJ (1990b) Fly larvae and their relevance in forensic toxicology. Am J Forensic Med Pathol 11(1):63-65

Levine B, Golle M, Smialek JE (2000) An unusual drug death involving maggots. Am J Forensic Med Pathol 21(1):59-61

Linville JG, Wells JD (2002) Surface sterilization of a maggot using bleach does not interfere with mitochondrial DNA analysis of crop contents. J Forensic Sci 47(5):1-5

Miller M, Lord W, Goff M, Donnelly B, McDonough E, Alexis J (1994) Isolation of Amitriptyline and Nortriptyline from fly puparia (Phoridae) and beetle exuviae (Dermestidae) associated with mummified human remains. J Forensic Sci 39(5):1305-1313

Nolte KB, Pinder RD, Lord WD (1992) Insect larvae used to detect cocaine poisoning in a decomposed body. J Forensic Sci 37(4):1179-1185

Oliveira HG, Gomes G, Morlin JJ, Von Zuben CJ, Linhares AX (2009) The effect of Buscopan on the development of the blow fly Chrysomya megacephala (F) (Diptera: Calliphoridae). J Forensic Sci 54(1):202-206

Pien K, Laloup M, Pipeleers-Marichal M, Grootaert P, De Boeck G, Samyn N, Boonen T, Vits K, Wood M (2004) Toxicological data and growth characteristics of single post-feeding larvae and puparia of Calliphora vicina (Diptera: Calliphoridae) obtained from a controlled nordiazepam study. Int J Legal Med 118(4):190-193

Sadler DW, Chuter G, Seneveratne C, Pounder DJ (1997a) Barbiturates and analgesics in Calliphora vicina larvae. J Forensic Sci 42(6):1214-1215

Sadler DW, Fuke C, Court F, Pounder DJ (1995) Drug accumulation and elimination in Calliphora vicina larvae. Forensic Sci Int 71(3):191-197

Sadler DW, Richardson J, Haigh S, Bruce G, Pounder DJ (1997b) Amitriptyline accumulation and elimination in Calliphora vicina larvae. Am J Forensic Med Pathol 18(4):397-403

Schloegl H, Dresen S, Spaczynski K, Stoertzel M, Martin Wurst F, Weinmann W (2006) Stability of ethyl glucuronide in urine, post-mortem tissue and blood samples. Int J Legal Med 120:83-88

Skopp G, Potsch L, Klingmann A, Mattern R (2001) Stability of morphine, morphine-3-glucuronide, and morphine-6-glucuronide in fresh blood and plasma and postmortem blood samples. J Anal Toxicol 25(1):2-7
Thiblin I, Eksborg S, Petersson A, Fugelstad A, Rajs J (2004) Fatal intoxication as a consequence of intranasal administration (snorting) or pulmonary inhalation (smoking) of heroin. Forensic Sci Int 139(2-3):241-247

Wallman JF (2001) A key to the adults of species of blowflies in southern Australia known or suspected to breed in carrion. Med Vet Entomol 15(4): 433-437

Wells JD, Introna F, Di Vella G, Campobasso CP, Hayes J, Sperling FA (2001a) Human and insect mitochondrial DNA analysis from maggots. J Forensic Sci 46:685-687

Wells JD, Pape T, Sperling FA (2001b) DNA-based identification and molecular systematics of forensically important Sarcophagidae (Diptera). J Forensic Sci 46(5):1098-1102

Wilson Z, Hubbard S, Pounder DJ (1993) Drug analysis in fly larvae. Am J Forensic Med Pathol 14(2):118-120

Wood M, Laloup M, Pien K, Samyn N, Morris M, Maes RAA, de Bruijn EA, Maes V, De Boeck G (2003) Development of a rapid and sensitive method for the quantitation of benzodiazepines in Calliphora vicina larvae and puparia by LC-MS-MS. J Anal Toxicol 27(7):505-512

\section{Publisher's Note}

Springer Nature remains neutral with regard to jurisdictional claims in published maps and institutional affiliations.

\section{Submit your manuscript to a SpringerOpen ${ }^{\circ}$ journal and benefit from:}

- Convenient online submission

- Rigorous peer review

- Open access: articles freely available online

- High visibility within the field

- Retaining the copyright to your article

Submit your next manuscript at $\boldsymbol{\nabla}$ springeropen.com 